\title{
VALIDASI METODE ANALISA PENETAPAN KADAR EPIGALOKATEKIN GALAT DENGAN KLT DENSITOMETRI
}

\section{VALIDATION METHOD OF QUANTITATIVE ANALYSIS OF EPIGALLOCATHECIN GALLAT BY THIN LAYER CHROMATOGRAPHY DENSITOMETRY}

\author{
Nining Sugihartini ${ }^{1,2}$, Achmad Fudholi ${ }^{3}$, Suwidjiyo Pramono ${ }^{3}$, Sismindari ${ }^{3}$ \\ Mahasiswa Program Pascasarjana, Fakultas Farmasi, \\ Universitas Gadjah Mada \\ Email:irmaningsih75@yahoo.com
}

\begin{abstract}
Abstrak
KLT Densitometri adalah salah satu metode yang banyak digunakan untuk penetapan kadar bahan aktif. Salah satu bahan aktif tersebut adalah epigalokatekin galat dalam ekstrak teh hijau yang banyak digunakan dalam produk krim. Metode tersebut perlu divalidasi untuk membuktikan hasil pengukuran mendekati kadar yang sesungguhnya. Tujuan penelitian ini ingin membuktikan bahwa metode KLT Densitometri yang digunakan akan memberikan linieritas, ketelitian, ketepatan yang memenuhi persyaratan serta mengetahui nilai LOD(Limit if Detection) dan LOQ (Limit of Quantitation). Penelitian menggunakan kadar 600, 1800 dan $3000 \mu \mathrm{g}$ dengan replikasi 3 kali untuk mengetahui ketelitian (berdasarkan nilai CV) dan ketepatan (berdasarkan nilai perolehan kembali). Linieritas diketahui dengan menghitung nilai $r$ pada kurva hubungan antara kadar dan luas area kromatogram yang selanjutnya persamaan kurva baku digunakan untuk menghitung LOD dan LOQ. Hasil penelitian menunjukkan bahwa metode yang digunakan memenuhi persyaratan liniearitas dengan nilai r=0,98. Nilai CV untuk kadar 600, 1800 dan 3000 ug masing-masing
\end{abstract}

\footnotetext{
${ }^{2}$ Fakultas Farmasi, Universitas Ahmad Dahlan

${ }^{3}$ Fakultas Farmasi, Universitas Gadjah Mada
} 
8,18\%; 3,19\% dan 1,53\% dan perolehan kembali masing-masing 88,10\%; 99,65\% dan 111,33\%. Nilai LOD adalah 827,01 $\mu \mathrm{g} / \mathrm{ml}$ dan LOQ adalah 2756,69 $\mu \mathrm{g} / \mathrm{ml}$.

Kata kunci : epigalokatekin galat, validasi, metode KLT Densitometri

\section{Abstract}

TLC Densitometry is one of method which was used to measure amount of active substance. Active substance of epigallocathechin gallate is one of in green tea extract cream. Method of analysis must be validated to prove that method will give the data close with the real value. Aim of this research is to prove that TLC Densitometry method have liniearity, precision and accuration that fulfill the requirement. This study used concentration 600, 1800 and $3000 \mathrm{ug} / \mathrm{ml}$ with 3 replications to measure precision (based on value of $\mathrm{CV}$ ) and accuration (based on value of recovery). Liniearity was known based on value of $r$ of curve regression between concentration and wide area of chromatogram. LOD and LOQ was calculated based on curve regression. Research showed that method of analyse had liniearity with $r=0,98$. Value of $C V$ concentration of 600,1800 and $3000 \mathrm{ug} / \mathrm{ml}$ were $8,18 \%, 3,19 \%$ and $1,53 \%$, respectively and recovery were $88,10 \%$; 99,65\% dan $111,33 \%$, respectively. Value of LOD was $827,01 \mu \mathrm{g} / \mathrm{ml}$ and LOQ was $2756,69 \mu \mathrm{g} / \mathrm{ml}$.

Keyword : epigallocathechin gallate, validation, KLT Densitometry method

\section{PENDAHULUAN}

Senyawa polifenol dalam teh hijau terutama epigalokatekin galat (EGCG) telah terbukti oleh banyak penelitian dapat digunakan sebagai senyawa pencegah kanker (Mukhtar dan Ahmad, 1999). Selain itu Hsu (2005) menyatakan bahwa telah ada 150 penelitian baik secara in vitro maupun in vivo yang membuktikan efek teh hijau pada kulit. Hasil penelitian tersebut menunjukan bahwa teh hijau berkhasiat sebagai senyawa kemopreventif terhadap senyawa karsinogen kimia maupun fotokarsinogen.
Berdasarkan khasiat ekstrak teh hijau yang mampu melindungi kulit maka semakin banyak produk perlindungan kulit yang menggunakan ekstrak tersebut. Efektivitas penggunaan produk tersebut sangat tergantung pada kadar EGCG yang ada. Oleh karena itu diperlukan metode penetapan kadar untuk mengetahui kadar EGCG dalam produk.

Kromatografi lapis tipis banyak digunakan di laboratorium untuk analisis maupun kontrol kualitas. Selain itu juga digunakan untuk menganalisa produk pertanian dan bahan tanaman. Keuntung- 
an analisis ini adalah mudah dilakukan, tersedianya reagen yang sensitif dan selektif yang tidak dipengaruhi oleh fase gerak. Penetapan kadar dengan menggunakan kombinasi KLT dan Densitometer (KLT Densitometri) cukup ekonomis karena menggunakan fase gerak yang sedikit, waktu yang relative singkat dan dapat dilakukan penetapan kadar beberapa sampel secara simultan. Apabila dibandingkan dengan KCKT maka metode KLT tidak ada batasan fase gerak yang harus digunakan, sampel yang berupa suspensi atau keruh dapat langsung ditetapkan kadarnya, lebih cepat dan ekonomis serta memungkinkan penetapan kadar secara simultan (Yuangsoi dkk., 2008)

Suatu metode analisa akan dapat memberikan data yang valid apabila telah dilakukan validasi sebelumnya. Parameter validasi tersebut meliputi linearitas, penetapan Limit of Detection (LOD) dan Limit of Quantification (LOQ), ketelitian dan ketepatan. Parameter tersebut perlu dievaluasi agar data yang diperoleh masuk dalam kemampuan alat tersebut untuk mendeteksi sehingga hasil yang diperoleh mendekati harga yang sebenarnya dan apabila diulang akan memberikan hasil yang sama. Apabila semua faktor sudah terpenuhi maka hasil yang diperoleh dapat dipertanggungjawabkan cukup valid. Metode analisa yang sudah divalidasi tersebut kemudian dapat diaplikasikan untuk berbagai keperluan misalnya penetapan kadar EGCG dalam ekstrak teh hijau, EGCG yang tertransport melewati kulit maupun EGCG yang ada dalam suatu produk.

\section{METODE PENELITIAN}

\section{Bahan dan Alat}

Bahan yang digunakan dalam penelitian ini adalah Standar epigalokatekin galat (E Merck), Butanol (derajat kromatografi), asam asetat (p.a), aquades dan silica gel F 254 sedangkan alat berupa KLT densitometer (Camag, Japan).

\section{Jalannya Penelitian}

\section{Kondisi KLT Densitometri}

Kadar EGCG dalam sampel ditetapkan dengan menggunakan fase diam silika gel F 254, dielusi dengan fase gerak campuran n-butanol, asam asetat dan air pada perbandingan 4:1:5 (fase atas) dan dilanjutkan pembacaan kadarnya pada panjang gelombang $303 \mathrm{~nm}$. Volume sampel yang ditotolkan sebanyak $5 \mu 1$.

\section{Ekstraksi EGCG dari krim}

Metode KLT Densitometri digunakan untuk penetapan kadar EGCG dalam krim. Metode pemisahan EGCG dari dalam krim adalah sebagai berikut : sebanyak 2 g krim ditambah $3 \mathrm{ml}$ metanol kemudian di sentrifuge dengan kecepatan 3000 rpm selama 30 menit sehingga terjadi 3 lapisan yaitu fase minyak, fase methanol-air dan endapan. Supernatan yang berupa fase minyak dibuang sedangkan fase metanol-airnya diekstraksi kembali menggunakan kloroform $3 \mathrm{ml}$ sebanyak 3 kali. Setelah disentrifus dengan kecepatan 3000 rpm selama 30 menit maka fase airnya 
kemudian ditambah metanol sampai volumenya $5 \mathrm{ml}$. Selanjutnya larutan tersebut ditetapkan kadar EGCG dengan kondisi seperti di atas.

\section{Parameter validasi}

a). Linearitas

Seri larutan baku dibuat pada konsentrasi 500, 1000, 1500, 2000, 3000, 3500, 4000 dan $4500 \mu \mathrm{g} / \mathrm{ml}$. Larutan kemudian ditotolkan pada fase diam dan selanjutnya dielusi. Hasil elusi selanjutnya dibaca dengan menggunakan Densitometer. Luas area yang dihasilkan dicatat dan dibuat persamaan linear hubungan antara kadar dan luas area yang dihasilkan. Nilai $r$ dari persamaan tersebut menggambarkan linieritas.

b) Penetapan LOD dan LOQ

Nilai LOD dan LOQ dihitung secara statistik berdasarkan persamaan regresi linear kurva baku yang diperoleh.

c). Ketelitian

Dilakukan pada ketelitian dibuat kadar 600, 1800 dan 3000 ug/ml dengan replikasi sebanyak 3 dan kemudian ditetapkan kadarnya dengan KLT Densitometer. Kadar sampel ditetapkan berdasarkan kurva baku yang sudah diperoleh. Selanjutnya dihitung kadar rata-rata, $\mathrm{SD}$ dan $\mathrm{CV}$.

d). Ketepatan (accuracy)

Pengujian dilakukan dengan menambahkan sejumlah EGCG murni ke dalam basis krim. Kemudian krim dianalisis dan hasilnya dibandingkan terhadap kadar EGCG yang ditambahkan (kadar sebenarnya).

\section{HASIL DAN PEMBAHASAN}

\section{Optimasi Fase Gerak}

Sampel hasil ekstraksi krim dielusi dengan fase gerak campuran butanol, asam asetat dan air pada perbandingan 4:1:5 dengan menggunakan fase diam silika GF 254. Hasil elusi menunjukkan bahwa proses ekstraksi telah dapat memisahkan EGCG dari basis krimnya dan komposisi fase gerak yang digunakan dapat mengelusi sampel dengan baik seperti yang disajikan pada gambar 1.

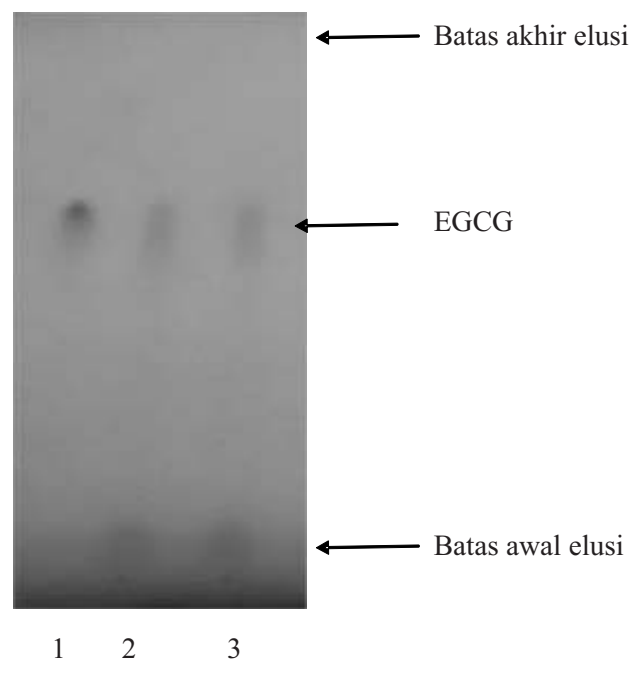

Gambar 1. Hasil elusi standar (1) dan sampel $(2,3)$ dengan fase gerak butanol:asam asetat:air(4:1:5) pada fase diam silica gel $F$ 254 


\section{Validasi Metode Analisa}

\section{Linieritas}

Linearitas dapat ditentukan dengan pengukuran pada beberapa konsentrasi analit. Nilai slope (b), intersep (a) dan koefisien korelasi (r) menggambarkan informasi liniearitas.

Hasil yang diperoleh dalam penelitian ini disajikan pada gambar 2 . Hasil perhitungan menunjukkan bahwa persamaan memberikan nilai $\mathrm{r} 0,98$. Nilai $r$ ini dibandingkan dengan nilai $r$ tabel untuk mengetahui validitas liniearitas. Apabila lebih besar dari $r$ tabel maka nilai $r$ cukup valid. Diketahui bahwa $r$ tabel 0,7067 sehingga persamaan regresi cukup liniear.

\section{LOD dan LOQ}

LOD adalah jumlah analit terkecil yang dapat dideteksi sedangkan LOQ adalah jumlah terkecil sampel yang dapat ditetapkan secara kuantitatif dengan presisi dan akurasi yang baik (Yuangsoi dkk., 2008). Hasil perhitungan menunjukkan bahwa LOD adalah 827,01 $\mu \mathrm{g} / \mathrm{ml}$ dan LOQ adalah $2756,69 \mu \mathrm{g} / \mathrm{ml}$.

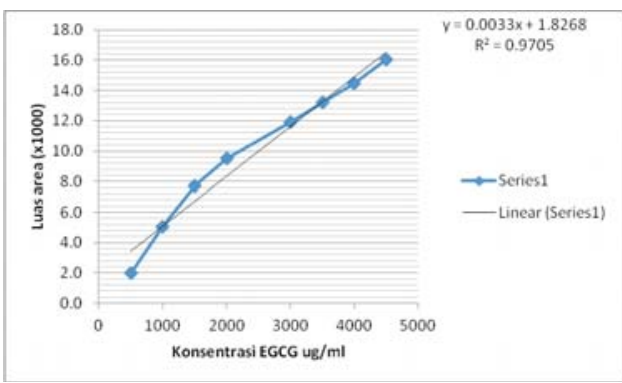

Gambar 2. Persamaan kurva baku EGCG dengan metode KLT Densitometri

\section{Ketelitian}

Pada penelitian ini digunakan tiga kadar yaitu 600,1800 dan $3000 \mu \mathrm{g} / \mathrm{ml}$ yang dibuat replikasi sebanyak 3 kali. Hasil perhitungan nilai $\mathrm{CV}$ disajikan pada abel I.

Tabel I. Nilai CV pada kadar 600, 1800 dan $3000 \mu \mathrm{g} / \mathrm{ml}$

\begin{tabular}{|c|c|c|c|}
\hline No. & $\begin{array}{c}\text { Kadar } \\
(\mu \mathbf{g} / \mathbf{m l})\end{array}$ & SD & CV (\%) \\
\hline 1. & 600 & 43,23 & 8,18 \\
\hline 2. & 1800 & 37,63 & 2,10 \\
\hline 3. & 3000 & 51,01 & 1,53 \\
\hline
\end{tabular}

Berdasarkan Association of Official Analytical Chemistry diketahui bahwa nilai $\mathrm{CV}$ yang memberikan ketelitian yang baik adalah apabila < 5,3\%. Demikian juga Meier dan Zund (2000) menyatakan bahwa metode memiliki ketelitian yang baik apabila memiliki CV kurang dari 5\%. Data pada tabel II menunjukkan bahwa nilai $\mathrm{CV}$ pada kadar $1800 \mu \mathrm{g} / \mathrm{ml}$ dan $3000 \mu \mathrm{g} / \mathrm{ml}$ memenuhi persyaratan ketelitian. Sedangkan pada kadar $600 \mu \mathrm{g} / \mathrm{ml}$ memiliki CV yang masih culup besar. Hal ini kemungkinan disebabkan konsentrasi tersebut berada di bawah batas deteksi alat sehingga kurang dapat memberikan hasil peng- ukuran yang teliti.

\section{Recovery}

Akurasi metode analisis adalah ukuran kedekatan hasil uji terhadap nilai sebenarnya yang dapat diterima (Anonim, 2006). Akurasi dihitung se- 
bagai persen recovery dengan menetapkan jumlah analit yang ditambahakan ke dalam sampel atau selisih antara rata-rata dan nilai sebenarnya yang dapat diterima. Kriteria tepat diberikan jika hasil analisis memberikan rasio antara 98-102\% (Ermer dan Miller, 2005). Hasil perhitungan rata-rata perolehan kembali disajikan pada Tabel II.

Tabel II. Rata-rata perolehan kembali pada kadar 600, 1800 dan $3000 \mu \mathrm{g} / \mathrm{ml}$

\begin{tabular}{|c|c|c|c|}
\hline No. & $\begin{array}{c}\text { Kadar } \\
\text { sesungguh } \\
\text { nya } \\
(\mu \mathbf{g} / \mathbf{m l})\end{array}$ & $\begin{array}{c}\text { Kadar } \\
\text { terukur } \\
(\boldsymbol{\mu g} / \mathbf{m l})\end{array}$ & $\begin{array}{c}\text { Recovery } \\
(\%)\end{array}$ \\
\hline 1. & 600 & 528,57 & 88,10 \\
\hline 2. & 1800 & 1793,43 & 99,65 \\
\hline 3. & 3000 & 3339,86 & 111,33 \\
\hline
\end{tabular}

Berdasarkan data pada tabel III diketahui bahwa perolehan kembali yang memenuhi persyaratan hanyalah pada penetapan kadar $1800 \mu \mathrm{g} / \mathrm{ml}$. Pada kadar $600 \mu \mathrm{g} / \mathrm{ml}$ tidak memenuhi persyaratan kemungkinan disebabkan karena kadar tersebut masih di bawah batas deteksi alat sehingga tidak dapat memberikan hasil pengukuran yang memenuhi syarat. Pada kadar $3000 \mu \mathrm{g} / \mathrm{ml}$ juga tidak memenuhi persyaratan kemungkinan disebabkan terdapat senyawa dalam krim selain EGCG yang ikut tersari sehingga mengganggu proses penetapan kadar.

\section{KESIMPULAN}

Hasil penelitian menunjukkan bahwa metode yang digunakan memenuhi persyaratan liniearitas dengan nilai $\mathrm{r}=0,98$. Nilai $\mathrm{CV}$ untuk kadar 600 , 1800 dan $3000 \mu \mathrm{g}$ masing-masing
$8,18 \% ; 2,10 \%$ dan $1,53 \%$ dan perolehan kembali masing-masing 88,10\%; $99,65 \%$ dan $111,33 \%$. Nilai LOD adalah $827,01 \mu \mathrm{g} / \mathrm{ml}$ dan LOQ adalah 2756,69 $\mu \mathrm{g} / \mathrm{ml}$.

\section{UCAPAN TERIMA KASIH}

Penelitian ini dibiayai oleh Ditjen DIKTI melalui anggaran BPPS Program S3 tahun 2007. Penulis juga mengucapkan terima kasih kepada Edi Budiharto dan Handi Widyatno atas bantuannya di Laboratorium.

\section{DAFTAR PUSTAKA}

Anonim, 2006, The United State Pharmacopeia, 29 th Ed., 3050-3053, United State Pharmacopeia Convention Inc., Rockville

Ermer, J. and Miller, H.M., 2005, Method Validation in

Pharmaceutical Analysis. A Guide to Best Practice, WILEY-VCH Verlag GmBH \& Co.KGaA, Weinheim

Hsu, S., 2005, Green Tea and The Skin, J. Am. Acad. of Dermatol., 52:1049-59

Meier, P, C dan Zund, R.E., 2000, Statictical methods in Analytical Chemistry, $2^{\text {nd }} \mathrm{Ed}$, 9, John Wiley \&Sons Inc., New York

Mukhtar, H. And Ahmad, N., 1999, Green Tea in Chemiprevention of Cancer, Toxicol Scie, 52:111-117

Yuangsoi, B., Jintasataporn,O., Areechon, $\mathrm{N}$ and Tabthipwon, $\mathrm{P}$., 2008, Validated TLC-densitometric analysis for 
determination of carotenoids in fancy carp (Cyprinus carpio) serum and the application for pharmacokinetic parameter assessment, Songklanakarin J. Sci. Technol., 30 (6), 693-700 